\title{
The Thematic Interpretation of Plural Nominalizations
}

\author{
Veronika Ehrich, \\ Tübingen University \\ veronika.ehrich@uni-tuebingen.de
}

\section{$1 \quad$ Introduction}

Nominalizations, in German as well as in other languages, are systematically polysemous, a fact that has been widely discussed in the linguistic literature (see, among others, Lees 1960; Vendler 1967; Chomsky 1970; Ehrich 1977, 1991; Bierwisch 1989; Zucchi 1989; Grimshaw 1990; Asher 1993; Pustejovsky 1995). A given nominal (NOM) allows for a wide range of possible interpretations and may denote an event (1a), a state (1b) or an object (1c).
(1) a. Event Nominal
Vor der Absperrung des Geländes machten die Arbeiter eine Pause.
Before fencing the site off, the workers had a break.
b. Resulting-State Nominal
While the site was fenced off, the number of burglaries decreased.
Während der Absperrung des Geländes sank die Zahl der Einbrüche.
c. Resulting-Object Nominal
Der Bulldozer durchbrach die Absperrung des Geländes.
The bulldozer broke through the fence of the site.

In this paper, I will discuss certain asymmetries concerning the interpretation of the postnominal genitive in constructions like (2) and (3).
(2) a. die Entlassung des Richters
the dismissal of the judge
b. die Vernehmung des Richters
the examination of the judge
(3) a. die Hinrichtung des Henkers
the execution of the executioner
b. die Hinrichtungen des Henkers
the executions of the executioner

The post-nominal genitive in (2a) unambiguously refers to the judge as the person who got dismissed. The post-nominal geni-tive in (2b), on the contrary, is ambiguous between two readings for the judge, as either the examiner or the examinee. The interpretation for the genitive in (3a) corresponds to that in (2a), the executioner is to be seen as referring to the victim of the execution (although world knowledge is inconsistent with this reading). Pluralization of the head nominal, however, alters the interpretation: the executioner is seen as carrying out the execution in (3b).

To put it briefly, the post-nominal genitive is sometimes ambiguous between a reading as AGENT or PATIENT, sometimes it just denotes the PATIENT, in other cases the AGENT of the action referred to. In the present paper, I will try to account for these asymmetries. Section 1 discusses former accounts of the problem. In section 2, I will develop a semantic representation for the argument structure of singular -ung-nominalizations. Section 3 will be 
devoted to the thematic interpretation of plural -ung-nominalizations. I will argue that the asymmetries illus-trated in (2-3) cannot be explained by reference to the concep-tual system, but form part of the grammar of - ung.

\section{The interpretation of -ung-nominalizations}

Past research on nominalizations has focussed on three kinds of mutually related problems: (i) the type-coercion problem (Pustejovsky 1995), (ii) the argument structure problem (Grimshaw 1990), (iii) the genitive interpretation problem (Lees 1960).

\subsection{Type Coercion (Pustejovsky's problem)}

The interpretation of a given nominal is resolved by reference to the meaning of a governing expression. Temporal prepositions like vor (1a) and während (lb) impose an eventive or stative reading onto their complements. Impact-by-contact verbs like durchbrechen (1c) induce an object reading. This contextual effect on the interpretation of a given nominal is called 'type coercion' in Pustejovsky (1995). The coercional force imposed by temporal prepositions is so strong that ordinary object nouns like Tisch ('table') or Suppe ('soup') are reinterpreted as event or state denoting expressions, when serving as complements to a temporal preposition (cf. Ehrich \& Rapp 2002).

(4) a. Sie haben sich nach Tisch gut unterhalten.

They had a nice conversation after table.

b. Sie haben sich während der Suppe gut unterhalten.

They had a nice conversation during the soup.

However, the interpretation of a given nominal is not solely de-termined by coercion. Each deverbal noun has its own semantic potential, depending on the lexical meaning of the underlying verb. Thus, while Bebauung ('covering with buildings') allows for a reading as event or result nominal (5), Erbaung ('con-structing a building') does not (6).

(5) a. Während der Bebauung des Potsdamer Platzes wurde der Verkehr umgeleitet.

During the be-build-ung ('remodelling') of the Potsdamer Platz the traffic got redirected.

b. Von der ursprünglichen Bebauung des Potsdamer Platzes ist nicht mehr viel übrig geblieben.

There isn't much left from the original be- build-ung ('buildings') of the Potsdamer Platz.

(6) a. Während der Erbauung des Anhalter Bahnhofs wurde der Verkehr umgeleitet. During the er-build-ung ('construction') of the Anhalter station the traffic got redirected.

b. *Von der ursprünglichen Erbauung des Anhalter Bahnhofs ist nicht mehr viel übrig geblieben.

There isn't much left from the original be-build-ung ('construction') of the Anhalter station.

In fact, we have to distinguish three parameters determining the interpretation of a given nominal: (i) the sortal requirements contextually coerced onto NOM by its linguistic context, (ii) the Lexico-Semantic Structure (LSS) of the base verb including its thematic structure and its situation type, and (iii) the contribution of the nominalizing affix. In this paper, I will take 
type coercion for granted, using matrix verbs and prepositions just as diagnostic contexts for the distinction between different readings of -ung-Nominalizations (NOM-ung).

\subsection{Argument Structure (Grimshaw's problem)}

Grimshaw (1990) discusses argument structure restrictions on different sorts of nominalizations. She distinguishes between complex event nominals (CEN) like (7) and result nominals $(\mathrm{RN})$, which occur as object nouns $(8 \mathrm{a}, \mathrm{b})$ or as event nouns $(9 \mathrm{a}, \mathrm{b})$.

\section{Complex Event Nominals (CEN)}

a. The professor's examination of the students took place in his office.

b. Edison's invention of the phonograph changed the world and made Edison rich.

c. Reagan's defeat of the liberals was a surprise.

Object Nominals (RN)

a. The professor's exam for the students is on the table.

b. Edison's invention is a useful device.

Simple Event Nominals (RN)

a. Reagan's defeat was a surprise.

b. John's murder was disastrous.

Grimshaw argues that CEN have argument structure, whereas RN don't. CEN-constructions having argument structure inherit both arguments of a transitive verb, such that the prenominal genitive corresponds to the verb's external, the post-nominal genitive to its internal argument. Where the internal argument of a verb is obligatory, its genitive counterpart is obligatory, too, which is why constructions like (10) are ungrammatical.

(10) a. *Cesar's ${ }_{\mathrm{AG}}$ destruction [_] PAT

b. *the professor's $\mathrm{AG}_{\mathrm{A}}$ examination []$_{\mathrm{P} \wedge \mathrm{T}}$

The nominals in (9) are to be analyzed as passive counterparts of the corresponding CEN constructions as in (7), the prenominal genitives thus correspond to the internal arguments of the respective base verbs; this is how we know that the genitive in (9b) refers to 'John' as the victim (PATIENT/THEME) of the murder. A correspondence like this is not to be considered a syntactic inheritance relation. The genitives in (9) are not arguments inherited from the verb, but argument adjuncts (AA), which bear just a conceptual (not a grammatical) relation to the underlying verb. AAs behave like adjuncts in terms of their syntax and may be omitted in constructions like the defeat, accordingly.

Grimshaw's analysis predicts that a construction spelling out both arguments of a transitive verb, is to be analyzed as CEN. It is therefore deviant in contexts which require a non-eventive complement as (11).

(11) a. *The professor's examination of the students is on the table.

b. *The invention of the phonograph is a useful device.

However, the absence of an internal argument by itself doesn't guarantee the accessibility of a non-eventive object reading. The ungrammaticality of $(6 b)$ is not due to the fact that the nominal Erbaung combines with an overt PATIENT (THEME) argument (Anhalter Bahnhof). Erbaung, as opposed to Bebauung, never adopts an object reading (see Bierwisch 1989), no matter whether the THEME argument is spelled out (6b) or not (12b).

(12) a. Die ursprüngliche Bebauung verfiel nach dem Krieg.

The original be-build-ung became dilapidated after the war. 
b. * Die ursprüngliche Erbauung verfiel nach dem Krieg.

The original er-build-ung became dilapidated after the war.

Although bebauen and erbauen are both change-of-state verbs, they differ with respect to the thematic status of their direct object. Bebauen is an applicative verb: it means 'cover with buildings' and its direct object, Potsdamer Platz in (5a), refers to a pre-existing area, which, as a result of the action, gets re-modelled by being covered with buildings. Erbauen is a creation verb, it means 'construct a building' and its direct object refers to the result of the action, the new building. In other words, Potsdamer Platz is GOAL in (5), Anhaller Bahnhof is THEME in (6). Adopting Dowty's (1991) notion of thematic proto-roles, one might say that the direct object of bebauen lacks one of the properties of PROTO-PATIENTS, the property of coming into existence, whereas the direct object of erbauen does have this property. In this sense, the direct object of erbauen is a better match for the role of PROTO-PATIENT than the direct object of bebauen, although both are incremental.

A nominalization complemented by both arguments of a transitive verb doesn't exclude an RN-interpretation (13), as is shown in Bierwisch (1989).

(13) a.

b.

Jonathan's description of the accident

c.

Beethoven's adaptation of the sonata $\}$ is on the table.

Meier's calculation of the costs

Describe, adapt, calculate are applicative verbs, denoting actions which apply to pre-existing objects and thereby create new objects, namely descriptions, adaptations, or calculations. The direct objects of these verbs and of the corresponding nominals do not denote the result of the action, i.e. the object created, but the entity being submitted to it. It is not the presence or absence of an internal argument which determines the accessibility of a RN interpretation. The critical point is rather that the nominal's referential argument (i.e. the thing that is a description, adaptation etc.) and its object (the accident, the sonata etc. in the example) ought to be referentially distinct.

The structural distinction between CEN and RN is less straight-foreward in German than it is in English. This is due to the fact that the prenominal possessive is fairly restricted (to the use of proper nouns). Constructions like (14a) are highly marked in German, where (14b,c) represent the structural prototype of a nominalization.

(14) a. ??des Feindes Zerstörung der Stadt the enemy's destruction of the city

b. die Zerstörung der Stadt (durch den Feind) the destruction of the city (by the enemy)

c. $\left[\mathrm{DP}\left[\mathrm{D}^{\prime} \mathrm{D}^{0}\right]\left[\mathrm{NP} \mathrm{N}^{0} \mathrm{DP}\right.\right.$ Gen $\left.]\right]$

This distribution suggests that nominalizations are never of type CEN in German. This implies - in Grimshaw's terms - that they never have argument structure. The genitives accompanying them in constructions like $(14 b, c)$ are then to be analyzed as AAs throughout.

\subsection{The thematic interpretation of the genitive (Lees' problem)}

As is well known since the days of Lees (1960) post-nominal genitives are often ambiguous between a reading as 'subject' or 'object' of the action referred to.

(15) a. the chasing of the hunters

b. the description of the student

c. the evaluation of the committee

d. the siege of the enemies 
Since a post-nominal Genitive must always be adjacent to $\mathrm{N}^{0}$ in German, there is just one slot to be filled by a post-nominal. The adjacency requirement has the effect that the AGENT and the PATIENT-argument of a transitive verb compete for sisterhood to the nominal head, which is why a post-nominal genitive can often be analyzed as either AGENT or PATIENT of the action referred to $(\mathrm{cf} 16)^{\mathrm{I}}$.

\section{AGENT}

a.
Die Befragung
The interrogation

b. Die Beobachtung

The observation

c. Die Durchsuchung The searching

d. Die Messung The measuring des Richters

of the judge

Galileis

of Galilei

der Grenzer

of the customs

des Ingenieurs

of the engineer

\section{PATIENT}

des Zeugen

of the witness

der Planeten

of the planets

der Reisenden

of the travellers

des Stroms

of the current

...geht weiter ('goes on').

However, not every nominal shares this behaviour. The geni-tives in $\left(16^{\circ}\right)$ do not permit an AGENT interpretation.

$\left(16^{\prime}\right)$
a. Die Beseitigung The removal
b. Die Erschießung The shooting
c. Die Entlassung The dismissal
d. Die Versendung The sending

AGENT

*des Mörders

of the murderer

* des Jägers

of the hunter

*des Ministers

of the Secretary

*des Autors

of the author

\section{PATIENT}

der Leiche

of the corps

des Hasen

of the rabbit

des Angestellten

of the employee

des Manuskripts

of the manuscript

...geschah unerwartet ('took place unexpectedly').

This discrepancy with respect to genitive interpretation is discussed in further detail in Ehrich \& Rapp (2000). In the present paper, I am mainly concemed with the thematic interpretation of post-nominal genitives complementing plura-lized heads (see section 1).

(17) a. die Hinrichtungen dieses Henkers

the executions of this executioner

b. die Erschießungen der Geheimpolizei

the shootings of the secret service

c. die Zubereitungen des Kochs

the preparations of the cook

The genitives in (17), as opposed to those in (16), have to be understood as representing the AGENT. Obviously, pluralization has an effect on the thematic interpretation of the nominal.

\footnotetext{
'I don't want to deny that the AGENT reading is more naturally conveyed by a prepositional form like die Befragung durch den Richter ("the interroggation by the judge'), probably because this form is unambigous. But the existence of an alternative to the genitive doesn't affect the ambiguity of the genitive in constructions like die Befragung des Richters ("the interrogation of the judge').
} 
This effect calls for an explanation.

\section{Argument Structure}

\subsection{Verb Argument Structure}

The argument structure (AS) of a verb specifies information about the verb's thematic structure and its situation type. Given a decompositional approach to verb semantics, the thematic structure (TS) of a verb is represented in terms of sublexical atomic predicates and their arguments ${ }^{2}$. Rapp $(1997,2001)$ distinguishes primitive predicates DO, BE, PSYCH, LOC, APPLY (18) and operators like BECOME, DEVELOP, CAUSE, which, applied to primitive predicates, yield complex predicates (19).
primitive predicates
a. frieren 'be cold'
$\mathrm{BE} \quad(\mathrm{x})$
b. lachen 'lough'
DO $(x)$
c. streicheln 'stroke'
d. wissen 'know'
DO $(x, y)$
e. umgeben'surround'
$\operatorname{PSYCH}(\mathrm{x}, \mathrm{y})$
APPL $(x, y)$

(19) complex predicates ${ }^{3}$
a. zerbrechen intr. 'break'
BECOME (BE (x))
b. zerbrechen trans 'break'
CAUSE $(<\mathrm{DO}(\mathrm{x}, \mathrm{y})>,<\operatorname{BECOME}(\mathrm{BE}(\mathrm{y}))>)$
c. lernen 'learn'
DEVELOP (PSYCH $(\mathrm{x}, \mathrm{y}))$
d. beibringen 'teach'
CAUSE $(<$ DO $(x)>,<\operatorname{DEV}(\operatorname{PSYCH}(\mathrm{z}, \mathrm{y}))>)$
e. erbauen 'construct a building'
CAUSE $(<$ DO $(\mathrm{x})\rangle,<\operatorname{DEVELOP}(\mathrm{BE}(\mathrm{y}))>$ )
f. bebauen 'cover with buildings'
$\operatorname{CAUSE}(<\operatorname{DO}(\mathrm{x}, \mathrm{y})>,<\operatorname{DEVELOP}(\operatorname{APPL}(\mathrm{z}, \mathrm{y}))>)$

Thematic roles making up the TS of a given verb are defined indirectly in terms of the position an argument has with respect to a primitive predicate (see for similar approaches Bierwisch 1997, Jackendoff 1983, 1990). Each primitive determines its own thematic hierarchy: the first argument is always higher in the hierarchy than the second.
Decomposition
Thematic Roles ${ }^{4}$
a. $\quad \mathrm{DO}(\mathrm{x})$
$x$ : AGENT
b. $\quad \operatorname{DO}(x, y)$
$\mathrm{x}$ : AGENT, $\mathrm{y}:$ PATIENT
c. $\quad B E(x)$
$\mathrm{x}$ : THEME
d. $\operatorname{PSYCH}(x, y)$
$\mathrm{x}$ : EXPERIENCER, $\mathrm{y}$ : ESTIMATUM
e. $\operatorname{LOC}(x, y)$
f. $\operatorname{APPL}(\mathrm{x}, \mathrm{y})$
$x$ : THEME, $y$ : PLACE
$\mathrm{x}$ : APPLICATUM, $\mathrm{y}$ : GOAL

\footnotetext{
${ }^{2}$ Shalley (2002) shows that abetract atomis predicates, which are often conflated in the decomposition structure of Indo-European verbs, have to be spelled out in languages like Walmajarri.

${ }^{3}$ Parentheses are printed in different types, where this helps to improve the legibility of the formula.

${ }^{4}$ Following Jackendoff (1990), PATIENT and THEME are considered distinct roles, see Rapp (1997a, 2001) and Ehrich \& Rapp (2000).
} 
According to general Verb Linking Principles (VLP), the highest argument of a given decomposition is linked to the highest structural position $\theta 1$ in syntax (21i). The AGENT $\mathrm{x}$ of (18c) or the EXPERIENCER $\mathrm{x}$ of $(18 \mathrm{~d})$ are thus linked to the position of $\theta 1$, whereas the PATIENT $y$ of (18c) or the ESTIMATUM y of (18d) are linked to the position of $\theta 2$ (VLP 21i), (see for details Rapp 2001).

Verb Linking Principles (VLP)

i Argument linking respects the thematic hierarchy. The higher argument (= the first argument) of a given primitive is linked to the highest structural position $\theta 1$, the lower argument is linked to $\theta 2$.

ii Arguments of DO have priority over arguments of other primitives.

iii If, according to (ii), the higher argument of a primitive cannot be linked to $\theta 1$, it is linked to an oblique position.

iv The oblique position for the EXPERIENCER is $\theta 3$. Other obliques are realized as prepositional adjuncts.

A linking conflict arises where complex predicates combine several primitives, for instance DO and PSYCH in (19d) or DO and APPL in (19f). The first argument $x$ of DO as well as the first argument $z$ of APPL in (19f) should be made subject of (22), if we adhere to VLP (21i). This linking conflict is resolved by the second VLP (21 ii), giving priority to the DO component. The AGENT $x$ is thus linked to $\theta 1$, the APPLICATUM $z$ to the position of an oblique (VLP 21 iii) and spelled out as a PP (VLP 21 iv) in (22).

(22) a. $\operatorname{Sie}_{x, 01}$ bebauen den Platz $z_{y}, 02$ mit Kaufhäusern $z$, oblique.

They cover the place with ware houses

CAUSE $(<\operatorname{DO}(\mathrm{x}, \mathrm{y})>,<\operatorname{DEVELOP}(\operatorname{APPL}(\mathrm{z}, \mathrm{y}))>)$

Primitive predicates always denote temporally open situations (states or activities). Adopting a multi-sortal neo-Davidsonian approach to argument structure, we represent the situation argument as part of the lexical decomposition. Reference to activities is represented by the process-variable $r$, reference to states by the state variable $s$.
a. $\operatorname{DO}((x, y), r)$
streicheln ('stroke')
b. $\quad B E((x), s)$
frieren ('be cold')
c. $\quad \operatorname{PSYCH}((x, y), s)$
bewundern ('admire')

The inchoative operators BECOME/DEVELOP turn the state predicates BE, PSYCH, LOC or APPL into a change-of-state predicate, the result is an achievement (BECOME) or an accomplishment (DEVELOP). Reference to a change of state is represented by the event variable e. CAUSE always combines with an inchoative operator (BECOME or DEVELOP) and never alters the situation type (24).
a. zerbrechen intr. ('break')
$\operatorname{BECOME}(\mathrm{BE}((\mathrm{x}), \mathrm{s}), \mathrm{e})$
b. zerbrechen $n_{\text {trans. }}$ ('break')
CAUSE $(<\operatorname{DO}((x, y), r)>,<\operatorname{BECOME}(\operatorname{BE}((y), s), e)>)$
c. lernen ('learn')
DEVELOP (PSYCH ((x,y), s), e)
d. beibringen ('teach')
CAUSE $(<\mathrm{DO}((\mathrm{x}), \mathrm{r})>,<\operatorname{DEVELOP}(\operatorname{PSYCH}((\mathrm{y}, \mathrm{z}), \mathrm{s}), \mathrm{e})>)$

Complex decomposition structures like (24 b-d) contain up to three different situation arguments. A given verb, of course, belongs to exactly one situation type. In fact, where the 
decomposition contains a process variable $r$, a state variable $s$ and an event variable e, the verb regularly refers to a situation of type e. This regularity is the reflex of a hierarchical ordering between situation types, as assumed in Ehrich \& Rapp (2000).

(25) i Situation Type Hierarchy (STH)

events: e > processes: $r>$ states: $s$

ii Situation Type Assignment

The situation argument ranking highest in STH is the referential argument of a complex decomposition structure.

The LSS of a complex predicate like transitive break can now be represented as in (26):

(26)

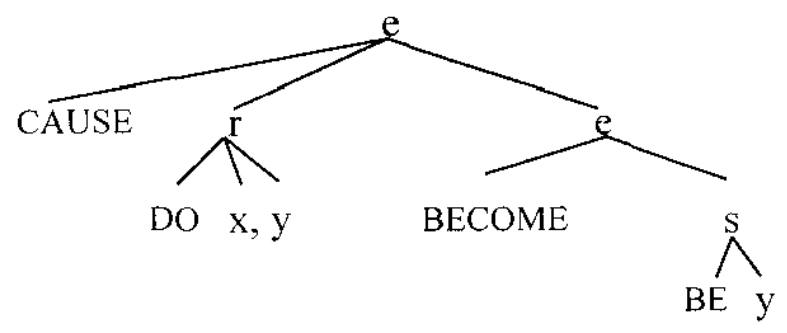

So far, we discussed thematic properties and situation properties making up the LSS of a given verb. We are now ready to consider Argument Structure (AS). Following Bierwisch's approach to AS, we represent the Semantic Form (SF) of a verb as composed of its AS and its LSS (see Späth (2002) for a similar model). Only those thematic arguments which project into syntax are part of a verb's AS. The AS furthermore contains the (silent) referential argument. Each LSS argument which belongs to AS is bound by lambda (27). LSS arguments which are not part of AS are left unbound.

(27) a. zerbrechenintr. ('break')

$\lambda \times \lambda$ e [BECOME $(\mathrm{BE}((\mathrm{x}), \mathrm{s}), \mathrm{e})]$

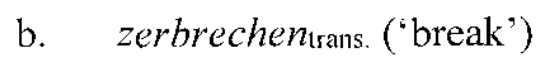

$\lambda$ y $\lambda \times \lambda$ e [CAUSE $(<$ DO $((x, y), r)>,<\operatorname{BECOME~}(\mathrm{BE}$

$((y), s), e)>, e)]$

c. lernen ('learn')

$\lambda y \lambda x \lambda$ e [DEVELOP (PSYCH $((x, y), s), e)]$

d. beibringen ('teach')

$\lambda \mathrm{z} \lambda \mathrm{y} \lambda \mathrm{x} \lambda \mathrm{e}[\mathrm{CAUSE}(<\mathrm{DO}((\mathrm{x}), \mathrm{r})>,<$ DEVELOP

$(\operatorname{PSYCH}((y, z), s), e)>, e)]$

Thematic LSS arguments which are obligatorily implicit in surface syntax are not bound by lambda (28a), optional thematic arguments (arguments which may, but need not be left implicit) are bound by a lambda in parentheses $(28 \mathrm{~b})^{5}$.

(28) a. schmausen

$\lambda \times \lambda \mathrm{r}[\mathrm{DO}((\mathrm{x}, \mathrm{y}), \mathrm{r})]$

b. kehren ('sweep')

$(\lambda y) \lambda \times \lambda r[D O((x, y), r)]$

\footnotetext{
${ }^{5}$ Constraints restricting the suppression of verb arguments are discussed in Ehrich $(1996,1997)$ and in Rapp (1977b).
} 


\subsection{Nominalization and Argument Structure}

Nominalization alters the argument structure of a given base verb in various ways. Thematic arguments complementing nominals as opposed to verbs are always optional. Hence, whereas AGENT and PATIENT are obligatory in the AS of befragen (29a), they are optional in in the AS of Befragung.

(29) a. Der Richter befragte *(den Zeugen) eine Stunde lang.

The judge interrogated the witness for an hour.

b. Die Befragung (des Zeugen) dauerte eine Stunde.

The interrogation of the witness took an hour.

Since nominals provide exactly one structural position for an NP-internal argument, only one of the verb's arguments can be linked to this position. This is why the genitive is ambiguous in constructions like die Befragung des Richters ('the interrogation of the judge'). However, as has been outlined above, this kind of ambiguity only arises in nominalizations of activities and states. Nominalizations of accomplishments and achievements like die Entlassung des Richters ('the dismissal of the judge') don't admit an AGENT interpretation (see 16, 16' above). Ehrich \& Rapp (2000) propose noun specific linking principles (NLP), which account for these differences (30).

$$
\text { Nominal Linking Principles (NLP) }
$$

i The lowest thematic argument of the inchoative component (BECOME / DEVELOP) has priority over all other components.

ii Arguments of the DO component have equal priority.

Befragen ('interrogate') refers to an activity (31a). The decomposition of the verb doesn't contain an inchoative component. NLP (30i) therefore doesn't apply to the correspon-ding NOM ('interrogation') in ( $31 \mathrm{~b}$ ), the thematic arguments $x, y$ have equal priority and are both bound by a lambda (put into parentheses because thematic arguments to NOM are always optional).

(31) a.

$$
\begin{aligned}
& \text { befragen ('interrogate') } \\
& \lambda y \lambda x \lambda \operatorname{r}[D O((x, y), r)]
\end{aligned}
$$

b. Befragung ('interrogation')

$$
(\lambda y)(\lambda x) \lambda r[D O((x, y), r)]
$$

Entlassen (32a) refers to an achievement (change of state); its PATIENT/THEME argument y has priority over all other argu-ments according to NLP (30i) and is bound by lambda (in parentheses again) in (32b); the AGENT argument $x$ must be left implicit and is thus left unbound.

$$
\begin{array}{ll}
\text { a. } & \text { entlassen ('dismiss') } \\
& \lambda \mathrm{y} \lambda \mathrm{x} \lambda \mathrm{e}[\operatorname{CAUSE}(<\mathrm{DO}((\mathrm{x}, \mathrm{y}), \mathrm{r})>,<\operatorname{BECOME}(\mathrm{BE}((\mathrm{y}), \mathrm{s}), \mathrm{e})>)] \\
\text { b. } & \text { Entlassung ('dismissal') } \\
& (\lambda \mathrm{y}) \lambda \mathrm{e}[\operatorname{CAUSE}(<\mathrm{DO}((\mathrm{x}, \mathrm{y}), \mathrm{r})>,<\operatorname{BECOME}(\mathrm{BE}((\mathrm{y}), \mathrm{s}), \mathrm{e})>)]
\end{array}
$$

Let us come back to bebauen ('cover with buildings'), erbauen ('construct a building') and the corresponding nominalizations. Both verbs refer to accomplishments, the event argument $\mathrm{e}$ is thus referential in (33a) and (34a), repectively, as well as in the decompositions of the corresponding event nominals $(33 \mathrm{~b}, 34 \mathrm{~b})$.

$$
\begin{aligned}
& \text { bebauen 'cover with buildings' } \\
& \lambda y \lambda x \lambda \text { e }[\operatorname{CAUSE}(<\operatorname{DO}((\mathrm{x}, \mathrm{y}), \mathrm{r})>,<\operatorname{DEVELOP}(\mathrm{z}, \mathrm{y}), \mathrm{s}), \mathrm{e})>)]
\end{aligned}
$$


(33') Bebauung Ev ('covering with buildings')

$(\lambda y) \lambda$ e [CAUSE $(<$ DO $((x, y), r)>,<\operatorname{DEVELOP}(\operatorname{APPL}((\mathrm{z}, \mathrm{y}), \mathrm{s}), \mathrm{e})>)]$

(34) erbauen ('construct a building')

$\lambda \quad$ y $\lambda \quad x \lambda$ e [CAUSE $(<\operatorname{DO}((\mathrm{x}), \mathrm{r})>,<\operatorname{DEVELOP}(\mathrm{BE}(\mathrm{y}), \mathrm{s}), \mathrm{e})>)]$

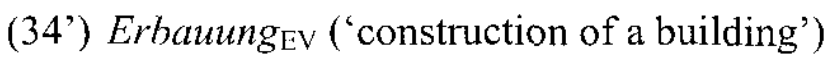

$(\lambda y) \lambda \mathrm{e} \quad[\operatorname{CAUSE}(<\mathrm{DO}((\mathrm{x}), \mathrm{r})>,<\operatorname{DEVELOP}(\mathrm{BE}((\mathrm{y}), \mathrm{s}), \mathrm{e})>)]$

The lowest argument y of the inchoative component has priority over the other arguments according to NLP (30i) and is thus bound by a lambda (in parentheses) in (33b, 34b). Bebauung has a second reading as resulting-object nominal (33c).

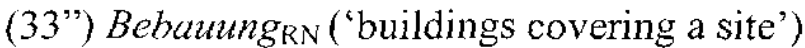

$$
(\lambda y) \lambda z \text { [CAUSE }(<D O((x, y), r)>,<\operatorname{DEVELOP}(\operatorname{APPL}((z, y), s), e)>)]
$$

The APPLICATUM $z$ is referential argument of (33"), the GOAL $y$ as lowest argument of the inchoative component is the single (but optional) thematic argument of (33"). The THEME argument $y$ of erbauen (34) is accessible as thematic argument of the nominalization according to NLP (30i). It cannot, at the same time, serve as referential argument, because this would violate the theta-criterion. This explains why Erbauung does not admit a resultingobject interpretation.

The NLPS in (30) form part of the grammar of German -ung-nominalizations, according to Ehrich \& Rapp (2000) but do not apply to implicit derivations (zero conversions) or nominalized infinitives $(35,36)$.

AGENT
a. der Schlag the hit
b. der Wurf the throwing
c. der Kuss the kiss

$$
\begin{aligned}
& \text { des Spielers } \\
& \text { of the player } \\
& \text { des Kriegers } \\
& \text { of the warrior } \\
& \text { der Spinne } \\
& \text { of the spider }
\end{aligned}
$$

$$
\begin{aligned}
& \text { PATIENT } \\
& \text { *des Balls } \\
& \text { of the ball } \\
& \text { *des Pfeil }_{\text {of the target }} \\
& \text { *der Spinne } \wedge \wedge \mathrm{T} \\
& \text { the kiss of the spider }
\end{aligned}
$$

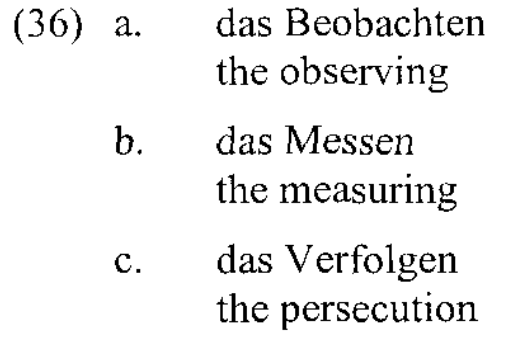

$$
\begin{aligned}
& \text { *des Astronomen } \\
& \text { of the astronomer } \\
& \text { *des Ingenieurs } \\
& \text { of the ingeneer } \\
& \text { *des Detektivs } \\
& \text { of the detective }
\end{aligned}
$$

\author{
des Planeten \\ the planet \\ des Stroms \\ of the current \\ des Diebs \\ of the burglar
}

Verbs like schlagen denote sequences of events (when viewed as iterations) or single events (semelfactives). Implicit derivations based on these verbs (35) are restricted to the semelfactive interpretation. This suggests that they behave like nominalizations of achievement verbs and allow for a PATIENT/THEME interpretation of the post-nominal genitive. But the genitives in (35) only permit an AGENT-interpretation. In-finitive conversions (36), on the other hand, though being based on activity verbs, are restricted to the PATIENT/THEME interpretation of the post-nominal genitive. Obviously, the NLPs nicely account for the interpretation of -ung-nominals, but don't apply to nominalizations of different morphological types. In other words, they belong to the grammar of -ung. 


\subsection{Argument Structure and Pluralization}

As far as pluralization is concerned, some nominals do undergo plural formation (37), others don't (38).

(37) a. Er beobachtete die beiden Zerstörungen der Stadt.

He observed both destructions of the city.

b. Die jährlichen Überprüfungen des Betriebs führen immer wieder zu Protesten. The annual controllings of the firm lead to protests over and over again.

c. Reinholds Besteigungen des K3 wurden von einem Fernsehteam gefilmt. Reinhold's climbings of the K.3 were filmed by a tv team.

(38) a. *Die Verzehrungen des Proviants waren erfrischend. The consumptions of the lunch were refreshing.

b. *Der Kontrolleur kritisierte die Verschwendungen des Etats. The controller criticized the wastings of the budget.

c. *Reinholds Erreichungen des Gipfels waren spektakulär. Reinhold's reachings of the summit werde spectacular.

The constraints underlying these differences are far from clear. One may argue that they are purely conceptual: a given amount of food can be consumed (a given budget wasted) just once, which is why the consumption (wasting) of something is a singularity. A given summit may, however, be reached more than once, even by the same mountaineer, but Erreichung ('reaching') doesn't undergo plural formation, either. This suggests that pluralizability is an idiosyncratic property of lexical items. Anyway, semantic constraints restricting plural formation are not at issue in this paper. I will rather restrict myself to the interpretation of the genitive in those forms which do undergo pluralization.

The nominal linking principles NLP introduced in (30) above even apply where they are inconsistent with encyclopedic knowledge (39).

(39) a. Die Hinrichtung des Henkers*AG/TH

The execution of the executioner

b. Die Verbrennung des Pyromanen * $\mathrm{AG} / \mathrm{TH}$

The burning of the pyromaniac

c. Die Erschießung des Jägers* $*_{A G} / \mathrm{TH}$

The shooting of the hunter

...geschah des Nachts ('happened at night').

As outlined above, the interpretation of the genitive changes, when the nominals get pluralized (40).

(40) a. Die Hinrichtungen des Henkers $\mathrm{AG}_{\mathrm{G} / * \mathrm{TH}}$

The executions of the executioner

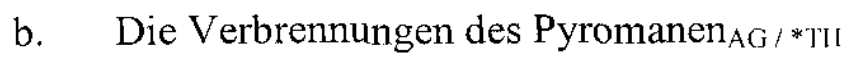

The burnings of the pyromaniac

c. Die Erschießungen des Jägers ${ }_{\Lambda \mathrm{G}} / * \mathrm{TH}$

The shootings of the hunter

...geschahen immer des Nachts ('always happened at night').

This discrepancy with respect to genitive interpretation might have an extralinguistic

\footnotetext{
${ }^{6}$ This insight goes back to Schäublin (1972) and Teubert (1978).
} 
explanation. A given individual can be executed, burnt or shot just once. Thus, the interpretation of the genitive as AGENT in (40) seems to result from a conceptual shift: Since the THEME/PATIENT reading of the genitive is, as a matter of fact, impossible, one has to reinterpret it as AGENT. This kind of re-interpretation allows us to understand sentences like (41):

(41) a. Die Hinrichtungen dieses Henkers sind besonders grausam.

The executions of (by) this executioner are extraordinarily cruel.

b. Die Verbrennungen dieses Pyromanen richten großen Schaden an.

The burnings of this pyromaniac cause huge damages.

c. Die Erschießungen der Geheimpolizei geschehen immer des Nachts.

The shootings of the secret police always take place at night.

The conceptual-shift analysis is, however, not applicable to the genitives in (42), which are ambigous between AGENT and PATIENT/THEME readings.

(42) a. die Vergiftungen des Apothekers $\mathrm{AG} / \mathrm{TH}$

the poisonings of the pharmacist

b. die Zerstörungen Roms ${ }_{\mathrm{AG} / \mathrm{TH}}$

the destructions of Rome

c. die Entsorgungen der Atomfirma $\mathrm{AG}_{\mathrm{G} / \mathrm{TH}}$

the disposals of the nuclear firm

Somebody may have been poisoned over again (as long as he wasn't given a lethal dose), Rome was destroyed several times in history, but (42) still is in opposition with the corresponding singular constructions in (43), where in accordance with NLP (30i) the genitives must be interpreted as PATIENT/THEME.

(43) a. die Vergiftung des Apothekers *AG/TH

the poisonings of the pharmacist

b. die Zerstörung Roms*AG/711

the destructions of Rome

c. die Entsorgung der Atomfirma $*_{\mathrm{AG} / \mathrm{TH}}$ the disposing of the nuclear firm

The asymmetries with respect to the interpretation of the genitive are not to be considered an effect of the plural as a morphological class. They can also be found in singular constructions with demonstratives or ordinals $(44)^{7}$.

(44) a. Die erste Hinrichtung dieses Henkers ${ }_{\mathrm{AG}}$ war besonders grausam.

The first execution of this executioner was extraordinarily cruel.

b. Nicht jede Vergiftung des Apothekers AG $_{\mathrm{i}}$ war erfolgreich.

Not every poisoning of the pharmacist was successful.

c. Die gestrige Beschädigung der Hooligans ${ }_{\mathrm{AG}}$ wird ein böses Nachspiel haben.

Yesterday's damaging of the hooligans will have bad consequences.

The nominals in $(41,42)$ directly denote pluralities, whereas those in (44) only presuppose that a selection is made from a plurality. We speak of a 'conceptual plural' in these cases.

The nominal linking principles introduced in section 2.2 imply that the genitive is ambiguous when complementing a process nominal (NLP 30ii). The explanation for the

\footnotetext{
${ }^{7}$ I owe this observation to Jack Hoeksema, Groningen (personal communication).
} 
thematic inter-pretation of the genitive adjoined to a morphological or con-ceptual plural is related to this principle in a very straight-forward way: plural converts an event nominal into a process-like nominal. The singulars in $(39,43)$ denote single events (= changes of states), the corresponding plurals denote sequences of iterated events. These are comparable to processes in terms of their temporal characteristics, which is why they combine with time-span predicates $(45,46)$.

(45) a. Die jahrelangen Hinrichtungen des Henkers hatten nach der Revolution ein Ende. The executions of the executioner which had been going on for years came to an end after the revolution.

b. Die mehrere Wochen andauernden Erschießungen der Polizei werden das Land noch lange traumatisieren.

The shootings of the police which had been going on for weeks will be traumatizing the country for long.

c. Die lang währenden Leerungen der Müllabfuhr verursachen schrecklichen Lärm. The time-consuming emptyings of the collection department cause terrible noises.

(46) a. Die über Monate fortgesetzten Vergiftungen des Liebhabers haben denEhemann langsam getötet.

The poisonings of the lover continued over months gradually killed the husband.

b. Die jahrelangen Zerstörungen der Armee haben die Bevölkerung zermürbt.

The destructions of the army going on for years wore people down.

d. Die wiederholten Entsorgungen der Firma rufen immer wieder Proteste hervor.

The repeated disposings of the nuclear company cause protests over and over again.

To put it briefly, eventive pluralities denote processes. As such they give equal priority to AGENT and PATIENT/THEME arguments (NLP 30ii). The PATIENT/THEME interpretation for the genitive in (41), on the one hand, is indeed ruled out by conceptual reasoning. The accessibility of an AGENT interpretation, on the other hand, is rooted in the linking principles of nominal grammar in German.

Link (1992) and Krifka (1992) reconstruct the meaning of plurals as denoting semilattices. The lower bound is given by the individual elements of the denotatum and the upper bound by the totality of joins of the individual elements. Plurals (of nominalizations as well as of ordinary base nouns) denote homogeneous objects comparable to the denotations of mass nouns. Their denotations are characterized by the specific mass noun properties: divisivity and cumulativity. ${ }^{8}$

Divisivity

For any denotation $D_{\text {phur }}$ of a noun with denotation $F$, there is a proper subpart

$D^{\prime}$ of $D_{\text {plur, such that }} \mathrm{D}^{\prime}$ is an instance of $F$.

ii Cumulativity

For any $\mathrm{D}^{\prime}$ joining the denotation $\mathrm{D}_{\text {plur }}$ of a noun with denotation $\mathrm{F}$, the resulting join is an instance of $F$.

These properties guarantee that morphologically pluralized or conceptually pluralic events behave like processes, which also implies that the corresponding nominals share the nominal

\footnotetext{
${ }^{8}$ This reconstruction of the plural meaning applies to any kind of common noun and is by no means specific for nominalizations. I will, therefore, not go into the details of this account. Alternative approaches are discussed in Schwarzschild (1996).
} 
linking properties of process nominals as defined in (30). The thematic interpretation of plural nominalizations is, thus, not inconsistent with the principles suggested in Ehrich \& Rapp (2000). On the contrary, the fact that eventive pluralities adopt the thematic properties of process nominals is a good confirmation of these principles.

Let us assume that Zerstörung denotes the set of all destruction events given in a domain $\mathrm{D}$, such that the denotatum ZERSTÖRUNG is a proper subset of the set of individual events (ZERSTÖRUNG $\subset \mathrm{D}_{\mathrm{ev}}$ ). Zerstörungen, then, denotes a semi-lattice composed of the totality of joins between elements of ZERSTÖRUNG. Let $\sum$ be a function, which, applied to the denotatum of a singular noun, gives us the corresponding plurality. Application of $\Sigma$ to the denotatum $\alpha \subset \mathrm{D}_{\mathrm{e}}$ of a singular event nominal then converts the situation type of $\alpha$, such that $\Sigma(\alpha) \subset D_{\text {proc. }}$. The nominal denoting $\Sigma(\alpha)$ is therefore subject to the linking principles for process nominals, no matter whether $\alpha$ is a process itself.

\section{Pluralization, Situation Type and Argument Structure}

i If $\alpha$ is the denotatum of a singular event nominal NOM-ung in the domain $D_{e v}$ of events, then Plur (NOM-ung) denotes an eventive plurality $\sum(\alpha)$ in the domain $\mathrm{D}_{\text {proc }}$ of processes.

ii Plur (NOM-ung) is subject to the linking principles defined forsingular process nominals of type NOM-ung.

\section{Conclusion}

In this paper, I discussed the interaction between situation type and thematic structure of ung-nominalizations. I argued that, whereas singular-ung-nominals share the situation type of their base verb, plurals always behave like process nominals. This has consequences with respect to argument structure. Singular nominals derived from change-of-state-verbs and the corres-ponding plurals show different linking patterns. While singular event nominalizations always give priority to the lowest argument of the inchoative component, their plurals share the linking pattern of singular process nominals and give equal priority to AGENT or PATIENT/THEME. This regularity conforms to the linking principles suggested in Ehrich \& Rapp (2000).

The evidences discussed so far have been reconstructed as properties inherent to the nominal grammar in German. Is this the only way to interpret the results? Wouldn't it be more convincing to argue instead that the interpretation of the adnominal genitive is not rooted in grammar, but in the conceptual system? ${ }^{?}$

Reference to conceptual reasoning may provide a nice explanation for the asymmetries between process nominals ( $=$ nominalizations of activities) on the one hand and event nominals (= nominalizations of accomplishments or achieve-ments) on the other hand. If we refer to an ongoing activity, both participants, AGENT and PATIENT/THEME are equally important: ignoring one of them makes us miss a relevant part of what is going on. In reference to a change of state (=event), it's much more relevant to be aware of what happens to the entity undergoing the change. This might be the reason why post-nominal genitives accompanying process nominals are ambiguous between AGENT and PATIENT/THEME readings, whereas genitives adjoined to event nominals unambiguously refer to PATIENTs/THEMEs.

There is, furthermore, good evidence that genitives complementing nominalizations in

\footnotetext{
9 The architecture of a two-level approach to meaning consisting of a conceptual and a semantic subsystem originally developed in Bierwisch (1983) and Bierwisch \& Lang (1987) is outlined in further detail in Wiese (2002)
} 
German aren't even arguments at all, but must be considered argument adjuncts in the sense of Grimshaw 1990, which is to say that German unlike English nominalizations never have argument structure, not even when they denote complex events (see sect. 1.2). This conclusion nicely fits the fact that obligatory verb arguments are optional, when showing up in nominalized constructions.

In this view, the nominal linking rules (NLP) introduced in section 2.2 above, have to be reconsidered as maxims guiding the conceptual interpretation of a given nominal. This doesn't make the evidences presented obsolete, but attributes a different theoretical status to them: they are facts not of the grammatical, but of the conceptual system.

Why then insist on the grammatical nature of the NLPs? The point is that the rules/maxims determining the thematic interpretation of post-nominal genitives only pertain to nominalizations with affix -ung. Implicit derivations (zero-con-versions) as well as infinitival conversions behave differently with respect to thematic interpretation (see section 2.2). This indicates that NLP (30) cannot be rooted in the conceptual system. If it were, the derivation type shouldn't make a difference. The very fact that it does suggests that the NLPs introduced above form part of the grammar of -ung.

\section{References}

Asher, Nicholas (1993): Reference to Abstract Objects in Discourse. Dordrecht: Kluwer.

Bierwisch, Manfred (1983): Semantische und konzeptuelle Repräsentation lexikalischer Einheiten. In: Rudolf Růžička / Wolfgang Motsch (eds.): Untersuchungen zur Semantik. Berlin: AkademieVerlag, 61-99.

Bierwisch, Manfred (1989): Event Nominalizations: Proposals and Problems. In: Linguistische Studien 194. Berlin, 1-73.

Bierwisch, Manfred (1997): Lexical Information from a Minimalist Point of View. In: Chris Wilder / Hans-Martin Gärtner / Manfred Bierwisch (eds): The Role of Economy Principles in Linguistic Theory. Berlin: Akademie-Verlag, 247-266.

Bierwisch, Manfred / Ewald Lang (1989): Dimensional Adjectives. Grammatical Structure and Conceptual Interpretation. Berlin, Heidelberg, New York: Springer.

Chomsky, Noam (1970): Remarks on Nominalization. In: R.A. Jacobs / P.S. Rosenbaum (eds): Readings in English Transformational Grammar. Waltham, Mass.: Ginn and Co.

Davidson, Donald (1967): The Logical Form of Action Sentences. In: Nicholas Rescher (ed.): The Logic of Decision and Action. Pittsburgh: University Press, 81-95.

Dowty, David (1979): Word Meaning and Montague Grammar. The Semantics of Verbs and Times in Generative Semantics and in Montague's PTQ. Dordrecht: Reidel.

Dowty, David (1991): Thematic Proto-Roles and Argument Selection. Language 67, 547 - 619.

Ehrich (Ullmer-), Veronika (1977): Zur Syntax und Semantik von Substantivierungen im Deutschen. Kronberg: Scriptor.

Ehrich, Veronika (1991): Nominalisierungen. In: Arnim von Stechow / Dieter Wunderlich (eds.), 229260.

Ehrich, Veronika (1996):Verbbedeutung und Verbgrammatik: Transportverben im Deutschen. In: Ewald Lang / Gisela Zifonun (eds.): Deutsch - typologisch. Berlin/New York: de Gruyter, 441458.

Ehrich, Veronika (1997): Wertsteigerung und Wertverlust - Die Veränderung der Valenz. In: Christa Dürscheid / Karl-Heinz Ramers / Monika Schwarz (eds.): Sprache im Fokus.Festschrift für Heinz Vater zum 65. Geburtstag. Tübingen: Niemeyer, 259-267.

Ehrich, Veronika / Irene Rapp (2000): Sortale Bedeutung und Argumentstruktur: ungNominalisierungen im Deutschen. Zeitschrift für Sprachwissenschaft 19, 245-303.

Ehrich, Veronika / Irene Rapp (2002): Nominalizations and Temporal Prepositions. This issue.

Grimshaw, Jane (1990): Argument Structure. Cambridge, Mass.: MIT Press.

Härtl, Holden / H. Tappe (eds.) (to appear): Structures and Processes at the Syntax-SemanticsInterface. Berlin: de Gruyter (=Trends in Linguistics). 
Jackendoff, Ray (1983): Semantics and Cognition. Cambridge, Mass.: MIT Press.

Jackendoff, Ray (1990): Semantic Structures. Cambridge, Mass.: MIT Press.

Krifka, Manfred (1991): Massennomina. In: Arnim von Stechow / Dieter Wunderlich (eds.), 399-417.

Lees, Robert B. (1960): The Grammar of English Nominalizations. The Hague /Paris: Mouton.

Lindauer, Thomas (1995): Genitivattribute. Eine morphosyntaktische Untersuchung zum DP/NPSystem. Tübingen: Niemeyer.

Link, Godehard (1991): Plural. In: Arnim von Stechow / Dieter Wunderlich (eds.), 418-440.

Pustejovsky, James (1991): The Syntax of Event Structure. Cognition 41: 47-81.

Pustejovsky, James (1995): The Generative Lexicon. Cambridge/Mass.: MIT Press.

Rapp, Irene (1997a): Partizipien und semantische Struktur: zu passivischen Konstruktionen im 3. Status. Tübingen: Stauffenburg-Verlag.

Rapp, Irene (1997b): Fakultativität von Verbargumenten als Reflex der semantischen Struktur. Linguistische Berichte 172, $490-529$.

Rapp, Irene (2001): Linking Steuerung im Verbalbereich: Welche Bedeutungsaspekte sind relevant? LAB 76/2001.

Schäublin, Peter (1972): Probleme des adnominalen Attributs in der deutschen Sprache der Gegenwart. Morphosyntaktische und semantische Untersuchungen. Berlin/New York: de Gruyter.

Schwarzschild, Roger (1996): Pluralities. Dordrecht: Kluwer.

Shalley, Andrea C. (2002): Competing Principles in the Lexicon. To appear in: Holden Härtl / H. Tappe (eds.).

Späth, Andreas (2002): The Linearization of Argument DPs and its Semantic Reflection. To appear in: Holden Härtl / H. Tappe (eds.).

Stechow, Arnim von / Dieter Wunderlich (eds.) (1991): Semantik: Ein internationales Handbuch der zeitgenössischen Forschung. Berlin: de Gruyter.

Teubert, Wolfgang (1979): Valenz des Substantivs: attributive Ergänzungen und Angaben. Düsseldorf: Schwann.

Toman, Jindřich $\left(1983^{87}\right)$ : Wortsyntax: Eine Diskussion ausgewählter Probleme deutscher Wortbildung. Tübingen: Niemeyer.

Vendler, Zeno (1967): Verbs and Times. In: Ders. Linguistics in Philosophy. Ithaca: Cornell University Press, 97-121.

Wiese, Heike (2002): Semantics as a Gateway to Language? To appear in: Holden Härtl / H. Tappe (eds.).

Zucchi, Alessandro (1993): The Language of Propositions and Events. Issues in the Syntax and the Semantics of Nominalization. Dordrecht: Kluwer. 